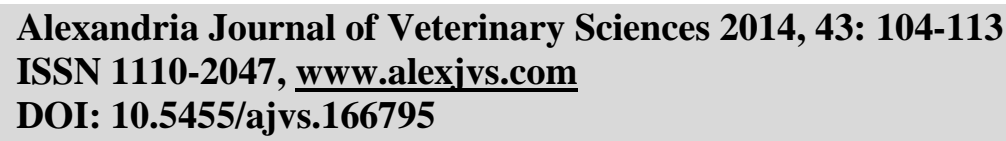

\title{
Some Studies on Heavy Metal Affecting Wild Catfish in Different Regions In Egypt
}

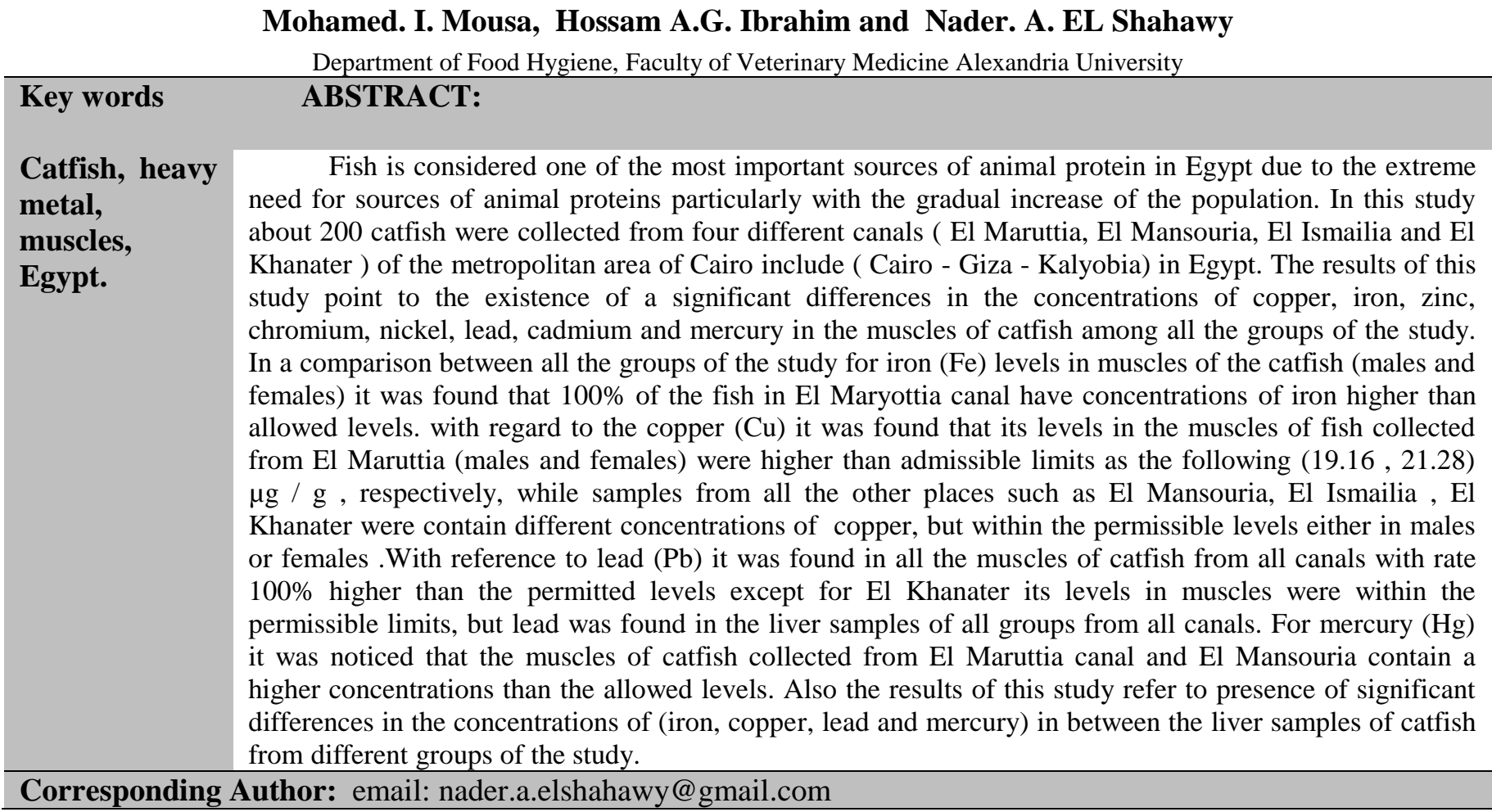

\section{INTRODUCTION}

Fish considered one of the main sources of the national income that Egypt depends on, stimulating local market economies, and important source of foreign exchange. In Egypt there is increasing rate of water pollution by the heavy metals due to an upsurge interest of construction of industrial plants on the banks of Nile river and its tributaries that discharge their chemical wastes in these canals resulting in pollution of the aquatic resources and accumulation of these metals in the meat of aquatic organisms like cat fish leading to serious health hazards for human consumers (Stephen et al., 2000).

Therefore, we have to explore this field to know how we can protect the Egyptian fresh water culture against these pollutants which will be reflected on human being. The present work aimed for monitoring of some heavy metal concentrations in both fish tissues and water in which fish is living.
In aquatic systems, heavy metals have received considerable attention due to their toxicity and accumulation in biota (Robenson, 2011) mentioned that metals generally enter the aquatic environment through atmospheric deposition, erosion of the geological matrix, or due to anthropogenic activities caused by industrial effluents, domestic sewage, and mining wastes. Some of these metals, such as $\mathrm{Cd}$ and $\mathrm{Pb}$, are toxic to living organisms even at quite low concentrations, whereas others, such as $\mathrm{Zn}$ and $\mathrm{Cu}$, are biologically essential and natural constituents of aquatic ecosystems, and generally only become toxic at very high concentrations. The effects of heavy metals on human health and the environment are of great interest today, especially for aquatic products (Uluozlu et al., 2007).

Symptoms related to prolonged low-level exposure may not be apparent until later in life and, when they do occur, may be chronic and irreversible. Serious illness due to long-term exposure to various 
toxic chemicals may include damage to the immune and nervous systems, impairment of reproductive function, cancer and organ-specific damage (WHO 1988).

\section{MATERIALS AND METHODS}

\section{1-Materials:}

\subsection{Fish sampling:}

Total number of two hundred fish of male and female freshwater catfish (clarias lazera) were collected from different locations along the Nile basin. The fish divided into four groups as following :

Twenty five male fish + twenty five female fish collected from Al Maruttia canal (Giza governorate). Twenty five male fish and twenty five female fish from Al Mansouria canal ( Giza governorate ).

Twenty five male fish and twenty five female fish collected from El Ismailia canal ( Cairo governorate ). Twenty five male fish and twenty five female fish from El Kanater El Khayria ( Kalyobia governorate ).

All fish samples were varied in length (between $25-30 \mathrm{~cm}$. ) and varied in weight (600-800 g. ) .

\subsection{Muscular tissues sampling and preparation:}

Dorsolateral muscles were rapidly removed from the killed fish and were stored in plastic container at $-20{ }^{\circ} \mathrm{C}$ for heavy metals residues analysis (Jonsson et al., 2012).

\subsection{Liver sampling and preparation :}

Livers were divided into two parts. The first of which connected to the dorsolateral muscles was stored in plastic container and kept at $-20{ }^{\circ} \mathrm{C}$ for heavy metals analysis. The second part was washed in water then cut into small fragments and homogenized with deionized water $(1 \mathrm{~g} / \mathrm{ml}$.) in a potter elvehjem homogenizer. The homogenate was used for measurement of different types of antioxidants (Mason, 1991).

\subsection{Biochemical analysis :}

A) Biochemical analysis of muscular tissues were used in the determination of (iron, copper, lead and mercury) residues.

B) Biochemical analysis of liver tissues were used in the following biochemical assays:

Detection of heavy metals residues.

Determination of different types of antioxidants markers (malondialdehyde MDA, reduced glutathione GSH, glutathione peroxidase GPX and glutathione-S-transferase GST).

C) Biochemical analyses of water were used for detection of heavy metals constituents.

\section{2-Methods:}

2.1. Heavy Metals (iron, copper, lead and mercury) in muscles of catfish :

Atomic absorption spectrophotometric method was used for the determination of copper, zinc, iron, chromium, mercury, cadmium, selenium, nickel and lead as described in Perkin Elemer catalogue of atomic absorption model 2380, U.S.A., (Jonsson et al., 2012 ).

2.2. Biochemical analysis of liver tissues for determination of (Heavy metals residues) :

A wet digestion procedure (Mason, 1991) was followed using pure conc. Nitric and perchloric acids in a ratio of 5:1 for each one gram of tissue in a Kjeldahl flask. The mixture was heated on a hot plate to a total colorless solution, then diluted with deionized water up to $50 \mathrm{ml}$. blank was treated in the same manner as samples.

Atomic absorption spectrophotometric method was used for the determination of copper, iron, zinc, chromium, mercury, cadmium, selenium, nickel and lead as described in Perkin Elmer catalogue of atomic absorption model 2380, U.S.A (1982). Atomic absorption with a single slot burner head that is capable of operating at the following wave length in (nm): 324.8, for $\mathrm{Cu}, 248.3$ for $\mathrm{Fe}$ and $\mathrm{Pb}$.

\subsection{Hg residues determination in liver Tissues :}

Accumulation of $\mathrm{Hg}$ in liver was measured colorimetrically by dithizone method as the following Principle :

Sample was digested with $\mathrm{HNO}_{3}$ and $\mathrm{H}_{2} \mathrm{SO}_{4}$ under reflux in special apparatus, $\mathrm{Hg}$ was isolated by dithiozone extraction, $\mathrm{Cu}$ was removed and $\mathrm{Hg}$ was estimated by photometric measurement of $\mathrm{Hg}$ dithizonate (Ates et al., 2008).

\subsection{Biochemical analysis of muscular tissuesfor} determination of heavy metals residues:

Accumulation of the heavy metals in the muscular tissues were measured using atomic absorption spectrophotometric method to determine copper, iron, zinc and other metals as previously described in liver tissues. Also mercury was measured calorimetrically as previously described in serum.

2.5. Biochemical analysis of liver fordetection of anti-oxidants (MDA, GSH, Gpx, GST ) :

Determination of malondialdehyde MDA(Allen et al., 2004):

Calculation: 
The absorbance was converted into $\mathrm{nM} / \mathrm{ml}$ using standard curve and expressed as $\mathrm{nM} \mathrm{MDA} / \mathrm{ml}$ plasma.

For the tissues, the total protein was determined in tissue homogenate according to Loucks et al. (2012) and the results were expressed as nM of $\mathrm{MDA} / \mathrm{mg}$ protein.

Determination of reduced glutathione GSH (Ciardullo, 2010):

\section{Method :}

1- $0.2 \mathrm{ml}$ of whole blood or tissue homogenate was added to $1.8 \mathrm{ml}$ of deionized dist. water. $0.2 \mathrm{ml}$ of the standard glutathione solution was added to $1.8 \mathrm{ml}$ of dist. water.

2- Allow to stand for no more than 3 minutes.

3- $3.0 \mathrm{ml}$ of precipitating solution was added to test and standard and mixed well. At the same time prepare a reagent blank by adding $3.0 \mathrm{ml}$ of precipitating solution to $2.0 \mathrm{ml}$ of deionized dist. water.

4- Allow to stand for 10 minutes.

5- Filter test, standard and blank solutions through Whatman no. 1 paper.

6- $0.5 \mathrm{ml}$ filtrate was added to $2.0 \mathrm{ml}$ of $0.3 \mathrm{M}$ $\mathrm{Na}_{2} \mathrm{HPO}_{4}$ and place in $3 \mathrm{ml}$ cuvette of $1 \mathrm{~cm}$ light path.

7- Read the optical density (OD) of the test and standard solutions at $412 \mathrm{~nm}$ against the reagent blank $\left(\mathrm{OD}_{1}\right)$.

8- Add $0.25 \mathrm{ml}$ of DTNB solution to blank, standard and test solutions. Mix well by inversion and immediately take a second OD reading against the reagent blank $\left(\mathrm{OD}_{2}\right)$.

\section{Calculation:}

As standard GSH solution concentration $=30$ $\mathrm{mg} / \mathrm{L}$ and Molecular weight of $\mathrm{GSH}=307$ then:

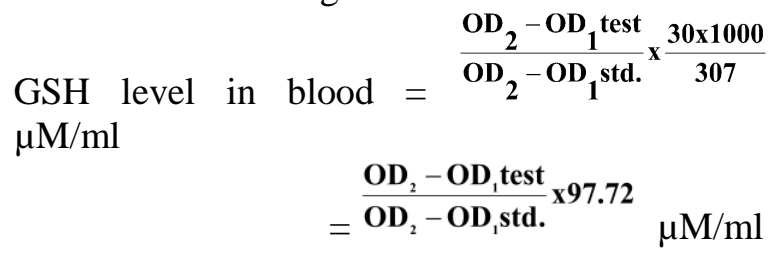

GSH concentration

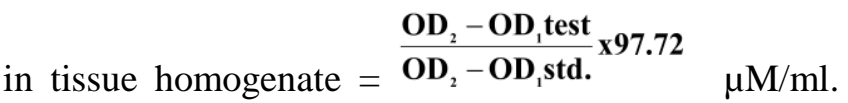
Total protein was determined in tissue homogenate according to Lowry et al. (1951).

GSH conc. $(\mu \mathrm{M} / \mathrm{ml})$

GSH conc. in tissues $=\overline{\text { Protein conc.(mg/ml) }} \mu \mathrm{M} / \mathrm{mg}$ protein.

Determination of glutathione peroxidase (Gpx, EC 1.11.1.9) (Pandeyet al., 2001):

Procedure:

Wave length: $340 \mathrm{~nm}$. Light path: $1 \mathrm{~cm}$.

Final volume: $3 \mathrm{ml}$ Temp. $\quad 20^{\circ} \mathrm{C}$.

Reading occurred against blank containing buffer and sample solution (hemolysate or homogenate) for test cuvette and buffer with dist. water for control cuvette. This was measured at $340 \mathrm{~nm}$ at $20^{\circ} \mathrm{C}$.

\section{Determination of glutathione-S-transferase (GST, EC 2.5.1.18) according to (Hajeb et al., 2012): Procedure:}

Light path $1 \mathrm{~cm}, \mathrm{pH} 6.5$ and final volume $3 \mathrm{ml}$ read at $25^{\circ} \mathrm{C}$ against blank.

\section{RESULTS and DISCUSSION}

In this study we used 200 catfish (100 male and 100 female) from four water sources in Delta and Cairo (Al Maruttia canal, Al Mansouria canal, El Ismalia canal, El Kanater Elkhayria), in addition to four water samples from the same water sources and the results would be classified as the following:

1- Determination of heavy metals (iron, copper, lead and mercury) in the muscles of cat fish that would be shown in the following tables $(1,3,5,7)$

2- Determination of heavy metals (iron, copper, lead and mercury) in the livers of cat fish that would be shown in the following tables $(2,4,6,8)$.

3- Determination of anti-oxidants MDA ,GSH ,GPX , GST) in the livers of cat fish that would be shown in the following tables $(9,10,11,12)$. 
Table (1): Analytical results of the Iron $((\mu \mathrm{g} / \mathrm{g})$ wet weight) of the examined samples of 25 cat fish meat.

\begin{tabular}{ccccccc}
\hline $\begin{array}{c}\text { Water } \\
\text { Channels }\end{array}$ & Sex & Minimum & Maximum & Mean \pm SEM & \multicolumn{2}{c}{ Samples above the permissible limits } \\
\cline { 6 - 7 } EL Maruttia & Male & 31 & 34 & $32.60 \pm 0.48^{\mathrm{a}}$ & 25 & Pumber \\
& Female & 29 & 35 & $32.82 \pm 1.02^{\mathrm{a}}$ & 25 & 100 \\
\multirow{2}{*}{ El Mansouria } & Male & 15 & 20 & $17.52 \pm 0.81^{\mathrm{bc}}$ & 0 & 0 \\
& Female & 15 & 20 & $17.96 \pm 0.84^{\mathrm{b}}$ & 0 & 0 \\
EL Ismailia & Male & 14 & 18 & $15.56 \pm 0.70^{\mathrm{c}}$ & 0 & 0 \\
& Female & 16 & 19 & $16.92 \pm 0.59^{\mathrm{bc}}$ & 0 & 0 \\
\multirow{2}{*}{ EL Khanater } & Male & 10 & 13.6 & $11.32 \pm 0.68^{\mathrm{d}}$ & 0 & 0 \\
& Female & 10 & 14 & $12.40 \pm 0.68^{\mathrm{d}}$ & 0 & 0 \\
\hline
\end{tabular}

Means carry different superscripts within the same column are significantly different $(\mathrm{P} \leq 0.05)$.

Table (2): Analytical results of the Iron $((\mu \mathrm{g} / \mathrm{g})$ wet weight $)$ of the examined samples of 25 cat fish liver.

\begin{tabular}{lcccccc}
\hline \multirow{2}{*}{$\begin{array}{c}\text { Water } \\
\text { Channels }\end{array}$} & Sex & Minimum & Maximum & Mean \pm SEM & \multicolumn{2}{c}{\begin{tabular}{c} 
Samples above the permissible \\
\cline { 5 - 6 }
\end{tabular}} \\
& & & & & Number & Percentage \\
\hline \multirow{2}{*}{ EL Maruttia } & Male & 82 & 90 & $85.50 \pm 1.47^{\mathrm{c}}$ & 25 & 100 \\
& Female & 85 & 91 & $88.24 \pm 1.07^{\mathrm{c}}$ & 25 & 100 \\
El Mansouria & Male & 215 & 230 & $222.40 \pm 2.56^{\mathrm{a}}$ & 25 & 100 \\
& Female & 209 & 230 & $219.60 \pm 4.00^{\mathrm{a}}$ & 25 & 100 \\
EL Ismailia & Male & 70 & 82 & $74.40 \pm 2.54^{\mathrm{d}}$ & 25 & 100 \\
& Female & 72 & 81 & $77.20 \pm 1.66^{\mathrm{d}}$ & 25 & 100 \\
EL Khanater & Male & 198 & 205 & $201.80 \pm 1.24^{\mathrm{b}}$ & 25 & 100 \\
& Female & 200 & 210 & $204.80 \pm 1.77^{\mathrm{b}}$ & 25 & 100 \\
\hline
\end{tabular}

Number of the samples $=25$.

$\mathrm{SEM}=$ Standard error for mean.

Means carry different superscripts within the same column are significantly different $(\mathrm{P} \leq 0.05)$.

Table (3): Analytical results of Copper $((\mu \mathrm{g} / \mathrm{g})$ wet weight $)$ of the examined samples of 25 cat fish meat.

\begin{tabular}{ccccccc}
$\begin{array}{c}\text { Water } \\
\text { Channels }\end{array}$ & Sex & $\begin{array}{c}\text { Minimu } \\
\text { m }\end{array}$ & $\begin{array}{c}\text { Maximu } \\
\text { m }\end{array}$ & Mean \pm SEM & \multicolumn{2}{c}{ Samples above the permissible limits } \\
\cline { 6 - 7 } EL Maruttia & Male & 15.9 & 21.4 & $19.16 \pm 0.93^{\mathrm{a}}$ & Number & Percentage \\
& Female & 19.8 & 23.1 & $21.28 \pm 0.62^{\mathrm{a}}$ & 25 & 100 \\
El Mansouria & Male & 4.9 & 6.8 & $5.76 \pm 0.37^{\mathrm{c}}$ & 0 & 0 \\
& Female & 3.9 & 6.2 & $5.12 \pm 0.38^{\mathrm{cd}}$ & 0 & 0 \\
EL Ismailia & Male & 3.2 & 4.2 & $3.74 \pm 0.19^{\mathrm{e}}$ & 0 & 0 \\
& Female & 3.8 & 4.9 & $4.12 \pm 0.20^{\mathrm{de}}$ & 0 & 0 \\
EL Khanater & Male & 1.1 & 1.7 & $1.40 \pm 0.11^{\mathrm{f}}$ & 0 & 0 \\
& Female & 1.2 & 1.9 & $1.54 \pm 0.13^{\mathrm{f}}$ & 0 & 0 \\
\hline
\end{tabular}

Means carry different superscripts within the same column are significantly different $(\mathrm{P} \leq 0.05)$. 
Table (4): Analytical results of Copper ( $\mu \mathrm{g} / \mathrm{g})$ wet weight) of the examined samples of 25 cat fish liver.

\begin{tabular}{lcccccc}
\hline \multirow{2}{*}{ Water Channels } & \multirow{2}{*}{ Sex } & \multirow{2}{*}{ Minimum } & \multirow{2}{*}{ Maximum } & \multirow{2}{*}{ Mean \pm SEM } & \multicolumn{2}{c}{ Samples above the permissible limits } \\
\cline { 3 - 7 } EL Maruttia & Male & 60 & 70 & $64.60 \pm 1.72^{\mathrm{a}}$ & 25 & Pumber \\
\cline { 2 - 7 } & Female & 61 & 72 & $65.60 \pm 2.25^{\mathrm{a}}$ & 25 & 100 \\
\hline \multirow{2}{*}{ El Mansouria } & Male & 39 & 48 & $42.60 \pm 1.60^{\mathrm{b}}$ & 25 & 100 \\
\cline { 2 - 7 } & Female & 39 & 44 & $41.80 \pm 1.02^{\mathrm{b}}$ & 25 & 100 \\
\hline \multirow{2}{*}{ EL Ismailia } & Male & 5 & 9 & $7.40 \pm 0.81^{\mathrm{c}}$ & 11 & 100 \\
\cline { 2 - 7 } & Female & 10 & 12 & $11.00 \pm 0.45^{\mathrm{c}}$ & 25 & 100 \\
\hline \multirow{2}{*}{ EL Khanater } & Male & 40 & 43 & $41.20 \pm 0.58^{\mathrm{b}}$ & 25 & 100 \\
\cline { 2 - 7 } & Female & 40 & 44 & $41.80 \pm 0.66^{\mathrm{b}}$ & 25 & \\
\hline
\end{tabular}

Means carry different superscripts within the same column are significantly different $(\mathrm{P} \leq 0.05)$.

Table (5): Analytical results of Lead $((\mu \mathrm{g} / \mathrm{g})$ wet weight) of the examined samples of 25 cat fish meat.

\begin{tabular}{|c|c|c|c|c|c|c|}
\hline \multirow{2}{*}{ Water Channels } & \multirow{2}{*}{ Sex } & \multirow{2}{*}{ Minimum } & \multirow{2}{*}{ Maximum } & \multirow{2}{*}{ Mean \pm SEM } & \multicolumn{2}{|c|}{ Samples above the permissible limit } \\
\hline & & & & & Number & Percentage \\
\hline \multirow{2}{*}{ EL Maruttia } & Male & 0.85 & 1.3 & $1.07 \pm 0.09^{\mathrm{bc}}$ & 24 & 96 \\
\hline & Female & 1 & 1.3 & $1.16 \pm 0.05^{\mathrm{bc}}$ & 25 & 100 \\
\hline \multirow{2}{*}{ El Mansouria } & Male & 1.8 & 2.9 & $2.30 \pm 0.18^{\mathrm{a}}$ & 25 & 100 \\
\hline & Female & 2 & 2.7 & $2.48 \pm 0.13^{\mathrm{a}}$ & 25 & 100 \\
\hline \multirow{2}{*}{ EL Ismailia } & Male & 1.5 & 2 & $1.80 \pm 0.09^{\mathrm{ab}}$ & 25 & 100 \\
\hline & Female & 1.9 & 2.3 & $2.04 \pm 0.07^{\mathrm{a}}$ & 25 & 100 \\
\hline \multirow{2}{*}{ EL Khanater } & Male & 0.299 & 3.52 & $0.95 \pm 0.64^{\mathrm{cd}}$ & 0 & 0 \\
\hline & Female & 0.219 & 0.332 & $0.30 \pm 0.02^{\mathrm{d}}$ & 0 & 0 \\
\hline
\end{tabular}

Table (6): Analytical results of Lead $((\mu \mathrm{g} / \mathrm{g})$ wet weight) of the examined samples of 25 cat fish liver.

\begin{tabular}{lcccccc}
\hline \multirow{2}{*}{ Water Channels } & \multirow{2}{*}{ Sex } & \multirow{2}{*}{ Minimum } & Maximum & \multirow{2}{*}{ Mean \pm SEM } & \multicolumn{2}{c}{ Samples above the permissible limits } \\
\cline { 6 - 7 } EL Maruttia & Male & 6.5 & 8.2 & $7.40 \pm 0.31^{\mathrm{cd}}$ & 25 & Percentage \\
& Female & 7.2 & 8.2 & $7.76 \pm 0.18^{\mathrm{bc}}$ & 25 & 100 \\
\multirow{2}{*}{ El Mansouria } & Male & 7.8 & 9 & $8.34 \pm 0.21^{\mathrm{ab}}$ & 25 & 100 \\
& Female & 8.1 & 9.3 & $8.90 \pm 0.23^{\mathrm{a}}$ & 25 & 100 \\
EL Ismailia & Male & 6 & 7 & $6.44 \pm 0.17^{\mathrm{e}}$ & 25 & 100 \\
& Female & 6.2 & 7.8 & $7.04 \pm 0.33 \mathrm{~d}^{\mathrm{e}}$ & 25 & 100 \\
EL Khanater & Male & 0.321 & 0.41 & $0.37 \pm 0.02^{\mathrm{f}}$ & 4 & 16 \\
& Female & 0.3 & 0.45 & $0.38 \pm 0.03^{\mathrm{f}}$ & 7 & 28 \\
\hline
\end{tabular}

Means carry different superscripts within the same column are significantly different $(\mathrm{P} \leq 0.05)$. 
Table (7): Analytical results of Mercury $((\mu \mathrm{g} / \mathrm{g})$ wet weight $)$ of the examined samples of 25 cat fish meat.

\begin{tabular}{ccccc} 
Water Channels & Sex & Minimum & Maximum & Mean \pm SEM \\
\hline \multirow{2}{*}{ EL Maruttia } & Male & 0.12 & 0.18 & $0.15 \pm 0.01$ \\
& Female & 0.11 & 0.18 & $0.14 \pm 0.01$ \\
\multirow{2}{*}{ El Mansouria } & Male & 0.00 & 0.16 & $0.11 \pm 0.03$ \\
& Female & 0.13 & 0.17 & $0.15 \pm 0.01$ \\
\multirow{2}{*}{ EL Ismailia } & Male & 0.03 & 0.14 & $0.07 \pm 0.02$ \\
& Female & 0.01 & 0.07 & $0.03 \pm 0.00$ \\
& Male & 0.00 & 0.04 & $0.02 \pm 0.00$ \\
& Female & 0.00 & 0.03 & $0.02 \pm 0.00$ \\
\hline
\end{tabular}

Means carry different superscripts within the same column are significantly different $(\mathrm{P} \leq 0.05)$.

Table (8): Analytical results of Mercury $((\mu \mathrm{g} / \mathrm{g})$ wet weight) of the examined samples of 25 cat fish liver.

\begin{tabular}{ccccc} 
Water Channels & Sex & Minimum & Maximum & Mean \pm SEM \\
\hline \multirow{2}{*}{ EL Maruttia } & Male & 0.07 & 0.12 & $0.09 \pm 0.01^{\mathrm{a}}$ \\
& Female & 0.05 & 0.09 & $0.07 \pm 0.01^{\mathrm{a}}$ \\
\multirow{2}{*}{ El Mansouria } & Male & 0.01 & 0.07 & $0.03 \pm 0.01^{\mathrm{b}}$ \\
& Female & 0.01 & 0.03 & $0.02 \pm 0.00^{\mathrm{b}}$ \\
& Male & 0 & 0.05 & $0.01 \pm 0.00^{\mathrm{b}}$ \\
EL Ismailia & Female & 0 & 0.06 & $0.01 \pm 0.00^{\mathrm{b}}$ \\
& Male & 0 & 0.1 & $0.02 \pm 0.00^{\mathrm{b}}$ \\
& Female & 0 & 0.09 & $0.02 \pm 0.00^{\mathrm{b}}$ \\
\hline
\end{tabular}

Means carry different superscripts within the same column are significantly different $(\mathrm{P} \leq 0.05)$.

Table (9): Analytical results of Malondialdehyde (MDA) of the examined samples of 25 cat fish liver.

\begin{tabular}{ccccc} 
Water Channels & Sex & Minimum & Maximum & Mean \pm SEM \\
& & & & \\
\hline \multirow{2}{*}{ EL Maruttia } & Male & 0.91 & 1.46 & $1.18 \pm 0.10^{\mathrm{cd}}$ \\
& Female & 0.89 & 1.97 & $1.34 \pm 0.20^{\mathrm{bc}}$ \\
El Mansouria & Male & 1.9 & 3.5 & $2.82 \pm 0.27^{\mathrm{a}}$ \\
& Female & 1.9 & 3.5 & $2.78 \pm 0.26^{\mathrm{a}}$ \\
EL Ismailia & Male & 1.3 & 2.1 & $1.72 \pm 0.15^{\mathrm{b}}$ \\
& Female & 1.5 & 2.1 & $1.76 \pm 0.11^{\mathrm{b}}$ \\
EL Khanater & Male & 0.71 & 0.95 & $0.81 \pm 0.04^{\mathrm{d}}$ \\
& Female & 0.61 & 0.96 & $0.79 \pm 0.06^{\mathrm{d}}$ \\
\hline
\end{tabular}

Means carry different superscripts within the same column are significantly different $(\mathrm{P} \leq 0.05)$. 
Table (10): Analytical results of Reduced glutathione (L- $\gamma$-glutamyl-L-cysteinylglycine, GSH) of the examined samples of 25 cat fish liver.

\begin{tabular}{ccccc} 
Water Channels & Sex & Minimum & Maximum & Mean \pm SEM \\
& & & & $90.46 \pm 2.79^{\mathrm{a}}$ \\
\hline \multirow{2}{*}{ EL Maruttia } & Male & 85.5 & 98.2 & $89.46 \pm 6.15^{\mathrm{a}}$ \\
\cline { 2 - 5 } & Female & 69.3 & 102.6 & $95.20 \pm 1.93^{\mathrm{a}}$ \\
\hline \multirow{2}{*}{ El Mansouria } & Male & 90 & 100 & $93.80 \pm 1.74^{\mathrm{a}}$ \\
\cline { 2 - 5 } & Female & 90 & 100 & $87.40 \pm 1.47^{\mathrm{a}}$ \\
\hline \multirow{2}{*}{ EL Ismailia } & Male & 82 & 90 & $87.40 \pm 3.20^{\mathrm{a}}$ \\
\cline { 2 - 5 } & Female & 81 & 99 & $68.20 \pm 3.68^{\mathrm{b}}$ \\
\cline { 2 - 5 } EL Khanater & Male & 60 & 77 & $65.40 \pm 2.94^{\mathrm{b}}$ \\
\cline { 2 - 5 }
\end{tabular}

Means carry different superscripts within the same column are significantly different $(\mathrm{P} \leq 0.05)$.

Table (11): Analytical results of (selenium dependent glutathione peroxidase, Gpx ) of the examined samples of 25 cat fish liver.

\begin{tabular}{ccccc} 
Water Channels & Sex & Minimum & Maximum & Mean \pm SEM \\
& & & & \\
\hline \multirow{2}{*}{ EL Maruttia } & Male & 102 & 110 & $106.00 \pm 1.30^{\mathrm{b}}$ \\
\cline { 2 - 5 } & Female & 104 & 111 & $108.20 \pm 1.24^{\mathrm{b}}$ \\
\hline \multirow{2}{*}{ El Mansouria } & Male & 92 & 104 & $98.40 \pm 2.38^{\mathrm{c}}$ \\
\cline { 2 - 5 } & Female & 90 & 100 & $93.80 \pm 1.69^{\mathrm{c}}$ \\
\hline \multirow{2}{*}{ EL Ismailia } & Male & 89 & 100 & $96.20 \pm 1.98^{\mathrm{c}}$ \\
\cline { 2 - 5 } & Female & 85 & 100 & $122.20 \pm 1.00^{\mathrm{c}}$ \\
\hline \multirow{2}{*}{ EL Khanater } & Male & 120 & 125 & $122.80 \pm 1.11^{\mathrm{a}}$ \\
\cline { 2 - 5 } & Female & 119 & 125 & \\
\hline
\end{tabular}

Means carry different superscripts within the same column are significantly different $(\mathrm{P} \leq 0.05)$.

Table (12): Analytical results of glutathione-S-transferases catalyses (GST) of the examined samples of 25 cat fish liver.

\begin{tabular}{ccccc} 
Water Channels & Sex & Minimum & Maximum & Mean \pm SEM \\
& & & & \\
\hline \multirow{2}{*}{ EL Maruttia } & Male & 206 & 217 & $210.40 \pm 1.86^{\mathrm{b}}$ \\
\cline { 2 - 5 } & Female & 214 & 225 & $218.20 \pm 1.98^{\mathrm{a}}$ \\
\hline \multirow{2}{*}{ El Manouria } & Male & 215 & 222 & $218.60 \pm 1.21^{\mathrm{a}}$ \\
\cline { 2 - 5 } & Female & 207 & 225 & $217.60 \pm 2.96^{\mathrm{a}}$ \\
\hline \multirow{2}{*}{ EL Ismailia } & Male & 200 & 206 & $207.60 \pm 1.03^{\mathrm{b}}$ \\
\cline { 2 - 5 } & Female & 205 & 210 & $185.60 \pm 0.86^{\mathrm{b}}$ \\
\hline \multirow{2}{*}{ EL Khanater } & Male & 174 & 195 & $181.00 \pm 2.53^{\mathrm{c}}$ \\
\cline { 2 - 5 } & Female & 175 & 190 &
\end{tabular}

Means carry different superscripts within the same column are significantly different $(\mathrm{P} \leq 0.05)$. 
The present work deals with the occurrence and distribution of heavy metals in water and their accumulation in the muscles and livers in Clarias lazera collected from four different locations ( El Maruotia, El Mansouria, EI Ismailia and EI khanater ), also the effects of exposure to pollutants including metals on some biochemical parameters in muscles and livers were investigated in this study.

\section{(A) Detection of heavy metals ( $\mathrm{Fe}, \mathrm{Cu}, \mathrm{Pb}$ and $\mathrm{Hg}$ ) in muscles and livers of Catfish :}

The results presented in this study revealed a wide significant variation in $(\mathrm{Fe}, \mathrm{Cu}, \mathrm{Pb}$ and $\mathrm{Hg}$ ) burdens in livers among the different investigated groups, as well in this study a high significant changes in $(\mathrm{Fe}, \mathrm{Cu}, \mathrm{Pb}$ and $\mathrm{Hg}$ ) were reported in the muscular tissues of Claria lazera trapped from different locations.

In the present study when the previous heavy metals contents for the investigated parts of cat fish ( Livers and muscles ) were compared with water concentrations of these metals at the investigated areas was shown to be highest for muscles for females as the following ( 32.82 $\pm 1.02, \quad 17.96 \pm 0.84$, $16.92 \pm 0.59$ and $12.4 \pm 0.68)$ respectively.

Fe levels in livers of male fish collected from (El Maruttia, El Mansouria, El Ismallia and El Khanater) were $(85.5 \pm 1.47,222.4 \pm 2.56,74.4 \pm 2.54$ and $201 \pm 1.24)$ respectively, but in livers of female fishes collected from (El Maruttia, El Mansouria, El Ismallia and $\mathrm{El}$ Khanater) were ( 88.25 \pm 1.07 , $219.6 \pm 4,77.2 \pm 1.66$ and $204.8 \pm 1.77$ ) respectively, but $\mathrm{Fe}$ accumulated only in the muscles of fishes over permissible limits was from El Maruttia males and females, only with the following levels $(32.6 \pm 0.48$ and $32.82 \pm 1.02$ ) respectively, while Fe levels in the muscles of $(\lesssim,+$ ) fishes collected from (El Mansouria, El Ismallia and El Khanater) were reported without significant flesh iron accumulation. The presence of a direct relationship between the concentration of iron $(\mathrm{Fe})$ in the flesh and its levels in the livers and muscles may confirm the previous observation. Also the highest bioaccumulation level of iron in spite of the relatively low level in water may be due to affinity of iron to chelate and precipitation with the sediment as recorded by (basholaf, 2009).

All of these above results are agree with the finding of (Sunderlandet al.,2012) who demonstrated that $(\mathrm{Fe}, \mathrm{Cu}, \mathrm{Pb}$ and $\mathrm{Hg}$ ) and other heavy metals mostly accumulated in liver followed by muscles, other investigations have also shown that the concentration of heavy metals were higher in the liver than in muscles (Sanchez, 2005).Fe \% is small and not affect human public health but with time meneral accumulation in fish muscle my accumulated in human liver causing toxicity and cancer. (Amaldin, 2008).

(B) Anti-oxidants (MDA, GSH, Gpx and GST) in livers of catfish:

\section{I- Malondialdehyde (MDA):}

Malondialdehyde (MDA) is a lipid degradation product (Roméo et al., 2000). It is formed by peroxidation of $\omega$ (polyunsaturated fatty acids) and $\omega 6$ PUFAs, and is used as a biological marker of oxidative stress (Dural et al., 2006).

Concerning the effect of heavy metals on MDA, our results agree with that recorded by Farag et al. (2006), they found that lipid peroxidation was increased by $30 \%$ in the liver of Oreochromis hornorum fish directly intoxicated with lead. Similar results was recorded by Gravato et al. (2006), they found that cadmium increased hepatic lipid peroxidation in Atlantic croaker and Clarias batrachus fish respectively. On the other hand our result disagree with that observed by Ternjej et al. (2010), they found that liver thiobarbituric acid reactant substances in rainbow trout remained unaffected by cadmium.

\section{II- Reduced glutathione (GSH):}

Reduced glutathione (L- $\gamma$-glutamyl-Lcysteinylglycine, GSH) is a major cellular antioxidant with numerous key functions (Orun et al., 2008). It plays an important role in metabolism of peroxides and free radicals, protecting cells from lipid peroxidation. It aids in maintenance of mitochondrial calcium content (Heath, 1995).

Kasheir et al.,(2004) attribute the increase of glutathione concentration observed in lead exposed fish to the increase in glutathione synthesis rather than a decrease in utilization.

\section{III- Glutathione peroxidase (Gpx) activity:}

Gpx (selenium dependent glutathione peroxidase) is the major effector in relieving oxidative stress by the conversion of GSH to GSSG with concomitant reduction of hydrogen peroxide $\left(\mathrm{H}_{2} \mathrm{O}_{2}\right)$ (Sivaperumal et al., 2007). Selenium dependent glutathione peroxidase reduces $\mathrm{H}_{2} \mathrm{O}_{2}$ (generated by superoxide dismutase) and organic peroxides (produced by the reaction of organic 
macromolecules with ROS (Reduced Oxidative Submutase) to water and alcohol respectively (Stephen et al., 2000).

\section{IV- Glutathione-S-transferase (GST) activity:}

The glutathione-S-transferases catalyses the conjugation of a wide variety of electrophilic compounds (endogenous substrates as well as xenobiotics) with

\section{REFERENCES}

Allen T., Singhal R., and Rana SV. 2004. Resistance to oxidative stress in a freshwater fish Channa punctatus after exposure to inorganic arsenic. Biological Trace Element Research 98, 63-72.

Amaldin, D.O. (2008). evaluation of public health efficacy due to mineral accumulation in different areas of Europe. Acta. Toxicol. Microb. Vol.5 No.2 , 243 256.

Ates B., Orun I., Talas ZS., Durmaz G., Yilmaz I. 2008. Effects of sodium selenite on some biochemical and hematological parameters of rainbow trout (Oncorhynchus mykiss Walbaum, 1792) exposed to $\mathrm{Pb} 2+$ and $\mathrm{Cu} 2+$. Fish Physiology and Biochemistry 34, 53-59.

Basholaf, P. R. 2009: Effect of processing pig manure in a biodigester as fertilizer input for ponds growing freshwater fish in polyculture. Livestock Research for Rural Development 13 (6) 2001. http://www.cipav.org.co/lrrd/lrrd13/6/pic 136.htm Ciardullo S., Aureli F., Raggi A., Cubadda F. 2010. Arsenic speciation in freshwater fish: Focus on extraction and mass balance. Talanta 81, 213-221.

Dural, M., Lugal M. Z., Ksu, G., Akif, A., Derici B. 2006. Bioaccumulation of some heavy metals in different tissues of Dicentrarchus labrax L., 1758, Sparus aurata L., 1758 and Mugil cephalus L., 1758 from the Camlik lagoon of the eastern coast of the Mediterranean (Turkey). Environmental Monitoring and Assessment, (118): $65-74$.

Emerit J., Beaumont C., Trivin F. 2001. Iron metabolism, free radicals, and oxidative injury. Biomedicine and Pharmacotherapy 55, 333-339.

FAO/WHO. 1984. List of maximum levels recommended for contaminants by the Joint FAO/ WHO Codex Alimentarius Commission. Second Series. CAC/FAL, Rome 3: 1-8.

FAO/WHO. 1992. Codex alimentarius commission, standard programme codex committee on food additives and contaminates. 24th Session, Hague, 23- 28 March, 1992.

FAO. 2010. Overview of Fish Production, Utilization, Consumption and Trade. FAQ, Rome, Italy.

Farag AM., May T., Marty GD., Easton M., Harper DD., Little EE., Cleveland L. 2006. The effect of chronic chromium exposure on the health of Chinook salmon (Oncorhynchus tshawytscha). Aquatic Toxicology 76, 246-257.

Gravato C., Teles M., Oliveira M., Santos MA. 2006. Oxidative stress, liver biotransformation and genotoxic effects induced by copper in Anguilla anguilla L. - the influence of pre-exposure to $\beta$-naphthoflavone. Chemosphere 65, 1821-1830.

Hajeb P., Jinap S., Ismail A., Mahyudin NA. 2012. Mercury pollution in Malaysia. Rev Environ Contam Toxicol. 2012;220:45-66. doi: 10.1007/978-1-46143414-6_2.

Heath, A. G. 1995. Water Pollution and Fish Physiology, CRC Press, Inc. Boca Rotan, Florida, 245 pp.

Jonsson S., Skyllberg U., Nilsson MB., Westlund PO., Shchukarev A., Lundberg E. and Björn E. 2012. Mercury methylation rates for geochemically relevant $\mathrm{Hg}$ (II) species in sediments. Environ Sci Technol. 2012 Nov 6;46(21):11653-9. doi: 10.1021/es3015327. Epub 2012 Oct 25

Kasheir, C. F., McNabb, C. D., Bartterson, T. R. 2004. Knud-Hansen Application of limnology for efficient nutrient utilization in tropic pond aquaculture. Verh. Internat. Verein Limnol., 24:2,541-2.543.

Loucks RH., Smith RE., Fisher CV. and Fisher EB. 2012. Copper in the sediment and sea surface microlayer near a fallowed, open-net fish farm. Mar Pollut Bull. 2012 Sep;64(9):1970-3.

doi: 10.1016/j.marpolbul.2012.05.025. Epub 2012 Jun 14.

Mason C. 1991. Biology of freshwater pollution. Longman Scientific and Technical, Harlow, England.

Orun I., Talas Z.S., Ozdemir I., Alkan A. and Erdogan K. 2008. Antioxidative role of selenium on some tissues of $(\mathrm{Cd} 2+, \mathrm{Cr} 3+)$-induced rainbow trout. Ecotoxicology and Environmental Safety 71, 71-75.

Pandey S., Ahmad I., Parvez S., Bin-Hafeez B., Haque R. and Raisuddin S. 2001. Effect of endosulfan on antioxidants of freshwater fish Channa punctatus Bloch: 1. Protection against lipid peroxidation in liver by copper preexposure. Archives of Environmental Contamination and Toxicology 41, 345-352.

Perkin Elemer, USA. 1982. Effect of probiotics supplementation with or without enzymes on the performance of male broiler chicks. M. V. Sc. Thesis submitted to ANGR Agricultural University, Hyderabad.

Robenson, P. T. K. 2011. Fish Diseases and disorders. Vol. 4 Viral, Bacterial and Fungal infections edited by P. T. K., New York, USA.

Romeo M., Bennani M., Gnassia-Barelli M., Lafaurie M. and Girard JP. 2000. Cadmium and copper display different response towards oxidative stress in the kidney of the sea bass Dicentrarchus labrax. Aquatic Toxicology 48, 185-194.

Ruas CBG., Carvalho CD., Araujo HSS., Espindola ELG. and Fernandes MN. 2008. Oxidative stress biomarkers 
of exposure in the blood of cichlid species from a metalcontaminated river. Ecotoxicology and Environmental Safety 71, 86-93.

Sadek, S. 2000. Seabream culture in Egypt; status, constraints and potential. Fish Physiol. Bioch., (22): 171 -178 .

Sanchez W., Palluel O., Meunier L., Coquery M., Porcher JM. and Aït-Aïssa S. 2005. Copper-induced oxidative stress in three-spined stickleback: relationship with hepatic metal levels. Environmental Toxicology and Pharmacology 19, 177-183.

Sivaperumal, P., Sankar, T. V. and Viswanathan-Nair, P. G. 2007. Heavy metal concentrations in fish, shellfish and fish products from internal markets of India vis-avis international standards. Food Chemistry, (102): 612 -620 .

Stephen, C., Jewett, A. and Sathy Naidu, A. 2000. Assessment of heavy metals in red king crabs following offshore placer gold mining. Mar. Pollut. Bull., (40): 478 - 490.

Sunderland EM., Amirbahman A, Burgess NM., Dalziel J., Harding G., Jones SH., Kamai E., Karagas MR., Shi X., Chen CY. 2012. Mercury sources and fate in the Gulf of Maine. Environ Res. 2012 Nov;119:27-41. doi: 10.1016/j.envres.2012.03.011. Epub 2012 May 8.

Ternjej I., Mihaljevic Z., Stankovic I., Kerovec M., Sipos L., Zeljezic D., Kopjar N. 2010. Estimation of DNA integrity in blood cells of eastern mosquitofish (Gambusia holbrooki) inhabiting an aluminium-polluted water environment: an alkaline comet assay study. Archives of Environmental Contamination and Toxicology 59, 182-193.

Toranzo, A. E., Santos, Y., Lemos, M. L., Ledo, A., Bolinches, J. 1987. Homology of Vibrio anguillarum strains causing epizootics in turbot, salmon and trout reared on the Atlantic coast of Spain. Aquaculture, (67): $41-52$.

Uluozlu, O. D., Tuzen, M., Mendil, D., Soylak, M. 2007. Trace metal content in nine species of fish from the Black and Aegean Seas, Turkey. Food Chemistry, (104): 835 - 840.

WHO. 1988. Environmental health criteria, Chromium. WHO, Geneva.

Woo, P. T. K., Bruno, D. W. 1999. Fish Diseases and disorders. Vol. 3 Viral, Bacterial and Fungal infections edited by P. T. K. Woo, New York, USA. 